\title{
Primary Aldosteronism: An Analysis by Speckle Tracking Echocardiography
}

\author{
Andryi Nykonenko ${ }^{1}$, Iryna Zubryk ${ }^{1}$, Oleksandr Podluzhnyi ${ }^{1}$, Olrksandr Molodan², \\ Sergii Bukhtii ${ }^{3}$, Oleksandr Nykonenko ${ }^{2}$ \\ ${ }^{1}$ Zaporizhzhya State Medical University, Zaporizhzhya, Ukraine \\ ${ }^{2}$ State Department "Zaporizhzhya Medical Academy of Postgraduate Education of Ukrainian Ministry \\ of Health Care", Zaporizhzhya, Ukraine \\ ${ }^{3}$ Vinmec International Hospital JCI, Hanoi Vietnam Anesthesiology and Pain Management Department
}

\begin{abstract}
SUMMARY
Remodeling of the myocardium in patients with primary aldosteronism (PA) is mediated by the presence of mineralocorticoid receptors on the myocytes and fibroblasts. The goal of this study was to analyze the effect of arterial hypertension and metabolic disorders on the cardiovascular system in patients with PA.

We recruited 54 patients with PA, $32(61.1 \%)$ female and $22(38.9 \%)$ male. The average age of the patients was $51.95 \pm 13.77$ years. There was a statistically significant negative correlation between the systolic blood pressure (SBP) and the longitudinal strain of the left ventricle (LV) at the basal level; a moderate negative correlation between the longitudinal strain of LV at the basal level and the aortic root diameter; a negative correlation between the circumferential strain of LV at the basal level and SBP, and a negative correlation between the circumferential strain of LV at the basal level and the aldosterone-renin ratio. The demonstrated correlations between SBP and longitudinal strain of LV at the basal level, diastolic blood pressure and circumferential strain of LV at the baselevel suggest thatleft ventricular hypertrophy in PA is preceded by the decrease not only in the longitudinal strain, as has been previously demonstrated, but also in the circular strain.
\end{abstract}

Key words: primary aldosteronism, hypertension, echocardioscopy, diagnostics

Corresponding author:

Iryna Zubryk

E-mail: lirinavit@gmail.com 


\section{INTRODUCTION}

The relationship between arterial hypertension and cardiovascular system has been addressed in numerous studies. This is also applicable to the endocrine arterial hypertension caused by primary aldosteronism (1, 2). According to Monticone S. et al., Conn's syndrome constitutes up to $5.9 \%$ of hypertension cases (3). The myocardium remodeling in these patients is mediated by the presence of mineralocorticoid receptors on the surface of cardiomyocytes and fibroblasts (4-6). Echocardiography is indispensable for evaluating cardiac structure and function. The advent of speckle-tracking of echocardiography, one of the strain imaging echocardiography modalities, allows for early detection of subclinical LV dysfunction (7-10).

The goal of this study was to analyze the effect of hypertension and metabolic disorders on the cardiovascular system in patients with primary aldosteronism.

\section{PATIENTS AND METHODS}

Overall 139 patients with adrenal pathology were examined and treated at the endocrine surgery department of Zaporizhzhia State Medical University between 2014 and 2018.

Primary aldosteronism was diagnosed in 54 patients, 32 (61.1\%) female and $22(38.9 \%)$ male. The average age was $51.95 \pm 13.77$ years. The duration of the illness was $84(48.00 ; 180.00)$ months. The average size of adrenal adenoma was $13(8.00 ; 19.30) \mathrm{mm}$.

The evaluation and treatment of primary aldosteronism was in accordance with the clinical practice recommendations for the management of Conn's syndrome $(11,12)$. The patients were assigned to one of the three groups. The first group included $25(46.3 \%)$ patients who underwent surgical treatment using endoscopic techniques (laparoscopic adrenalectomy (LAE) and laparoscopic partial adrenalectomy (LPAE). The second group included 16 (29.6\%) patients who underwent an x-ray endovascular destruction of the adrenal (REVD). The third group included $13(24.1 \%)$ patients treated conservatively.

Echocardioscopy (ECS) was performed on ultrasound machines "ULTIMA PRO 30" (Ukraine) and "ACUSON X 700" (Siemens, Germany). The evaluation included the size of the heart chambers, systolic and diastolic function of the myocardium, presence of pericardial effusion, position, shape and function of the cardiac valves; myocardial walls thickness at the LV posterior wall and intervetricular septum; LV stroke volume (SV LV), end-systolic (CED) and end-diastolic (EDD) dimensions of LV, end-systolic (ESV) and end-diastolic (EDV) volumes of LV, left ventricular mass (LVM), aortic root diameter (ARD) and main pulmonary artery diameter (MPAD). Two-dimensional speckle-tracking ECS was performed in 13 patients $(24.07 \%)$ to measure the longitudinal strain of the left ventricle (LS LV), circumferential strain at the basal (CSBA) and apical levels (AA LV), and the average global strain of the left ventricle (AGS LV).

Statistical analysis was performed with Statistica version 6.0 software (StatSoft, USA). The Kolmogorov-Smirnov test and Shapiro-Wilktest were used to determine the variables that follow the normal distribution pattern. We compared the normally distributed variables using the Student's t test. For the variables that did not follow the normal distribution and variables obtained from a small sample size, we used non-parametric methods (Mann-Whitney, WaldWolfowitz, Kolmogorov-Smirnov's criteria for unbound groups; Wilcoxon's sign criteria for related groups). To assess the relationship between the variables that have a normal distribution, we calculated the Pearson's correlation coefficient; for the variables that follow other distribution patterns, the Spirman coefficient was used. Values below 0.25 indicated a weak relationship, values that fall into the 0.25-0.75 range indicated a moderate correlation, and values from 0.75 to 1.0 indicated a strong correlation. For the variables that follow a normal distribution, we calculated the average value and standard deviation $(\mathrm{M} \pm \sigma)$; for any other variables we calculated the median, 25 and 75 percentiles [Me (25\%, 75\%)]. P value $<0.05$ was considered statistically significant.

The study was performed according to the Declaration of Helsinki, procedures were approved by the local ethics committee.

\section{RESULTS}

The average SBP was $174.14 \pm 18.02 \mathrm{~mm} \mathrm{Hg}$, average diastolic blood pressure was 100.00 (100.00; $110.00) \mathrm{mm} \mathrm{Hg}$. The mean levels of aldosterone was $423.96 \pm 187.14 \mathrm{pg} / \mathrm{ml}$, renin $8.09(2.00,26.68) \mathrm{pg} / \mathrm{ml}$, aldosterone-renin ratio $77.15(20.51 ; 125.46)$, potassium $3.93(3.76 ; 4.20) \mathrm{mmol} /$ liter. There was no correla- 
tion between the duration of hypertension and the degree of blood pressure elevation ( $p>0.05)$. No correlations were also demonstrated between the illness duration, plasma aldosterone level, and aldosteronerenin ratio ( $p>0.05)$, as well as between the hormonalactive adenoma/adrenal hyperplasia size and aldosterone level $(p>0.05)$.

The average thickness of the interventricular septum was $12.74 \pm 2.84 \mathrm{~mm}$, the $\mathrm{LV}$ posterior wall was $12.00(11.00 ; 12.00) \mathrm{mm}$; left ventricular mass was $254(200.00 ; 332.00) \mathrm{g}$, stroke volume (SV) was $66.4 \pm$ $8.06 \%$.

The characteristics of structural and functional heart changes according to Echo-CS in patients with Conn's syndrome by the study group are shown in Table 1.

Table 1. Structural and functional characteristics of the heart in patients with Conn's syndrome by echocardioscopy

\begin{tabular}{c|c|c|c}
\hline \hline $\begin{array}{c}\text { Indicator, unit of } \\
\text { measure }\end{array}$ & $\begin{array}{c}1^{\text {st }} \text { group } \\
\text { LAE/ LPAE } \\
(\mathrm{n}=25)\end{array}$ & $\begin{array}{c}2^{\text {nd }} \text { group } \\
\text { REVD }^{* * * *} \\
(\mathrm{n}=16)\end{array}$ & $\begin{array}{c}3^{\text {rd }} \text { group } \\
\text { Conservative } \\
\text { treatment } \\
(\mathrm{n}=13)\end{array}$ \\
\hline IVST, mm & $12.30(11.00 ; 13.50)$ & $12.36 \pm 2.44$ & $11.9 \pm 1.88$ \\
\hline TPW LV, mm & $12.38 \pm 2.29$ & $11.59 \pm 89$ & $11.66 \pm 2.05$ \\
\hline LVM, g & $255.5(208.5 ; 333.5)$ & $236.60 \pm 79.97$ & $271.25 \pm 102.59$ \\
\hline SV, $\%$ & $62.48(58.43 ; 68.00)$ & $68.51 \pm 9.79$ & $69.66 \pm 7.55^{* *}$ \\
\hline ESD LV,mm & $32.14 \pm 5.60$ & $28.50(25.00 ; 34.00)$ & $28.02 \pm 8.55$ \\
\hline EDD LV,mm & $52.04 \pm 5.30^{*}$ & $47.5(45.00 ; 51.00)$ & $51.42 \pm 8.28$ \\
\hline ECV LV, ml & $48.14 \pm 17.00$ & $40.01 \pm 13.40$ & $42.40 \pm 21.64$ \\
\hline EDV LV, ml & $137.31 \pm 29.24$ & $117.87 \pm 23.36$ & $148.60 \pm 50.28$ \\
\hline \hline
\end{tabular}

Note 1. The data is given as $\mathrm{Me}(\mathrm{Q} 25 ; \mathrm{Q} 75)$ or $\mathrm{M} \pm \mathrm{m}$ depending on the nature of the data distribution. Note $2{ }^{*}$ The probability of difference between $1^{\text {st }}$ and $2^{\text {nd }}$ patient groups $(p<0.05)$.

Note 3 . $^{* *}$ The probability of difference between $1^{\text {st }}$ and $3^{\text {rd }}$ group of patients $(p<0.05)$.

Note 4. ${ }^{* * *}$ LAE- laparoscopic adrenal ectomy. LAPR- laparoscopic adrenal partial resection.

Note 5. ${ }^{* * *}$ Roentgen-endovascular destruction of adrenal.

Table 2. Analysis of the correlation between the structural and functional characteristics of the heart in patients with Conn's syndrome according to the data of echocardioscopy and blood pressure, aldosterone, aldosterone-rennin ratio (ARR)

\begin{tabular}{c|c|c|c|c}
\hline \hline Indicator, unit of measure & SBP, $\mathrm{mm} \mathrm{Hg}$ & $\mathrm{DBP}, \mathrm{mm} \mathrm{Hg}$ & Aldosterone, $\mathrm{pl} / \mathrm{ml}$ & ARR \\
\hline TIS, $\mathrm{mm}$ & 0.17 & 0.17 & -0.05 & 0.06 \\
\hline TPV LV, $\mathrm{mm}$ & 0.25 & 0.13 & -0.070 & -0.03 \\
\hline LVM, g & 0,30 & 0.22 & -0.124 & 0.07 \\
\hline SV, $\%$ & 0.19 & 0.051 & 0.04 & -0.07 \\
\hline ESD LV, mm & -0.28 & -0.20 & -0.11 & -0.17 \\
\hline EDD LV,mm & -0.03 & -0.05 & -0.03 & -0.10 \\
\hline ECV LV, mm & 0.24 & 0.11 & -0.01 & 0.04 \\
\hline EDV LV, mm & 0.147 & -0.170 & -0.03 & -0.18 \\
\hline RL LV, $\%$ & $-0.80^{*}$ & -0.38 & -0.28 & $-0.68^{*}$ \\
\hline CSBA LV, $\%$ & -0.27 & $-0.56^{*}$ & -0.20 & -0.47 \\
\hline CSAA LV, $\%$ & -0.55 & -0.32 & -0.01 & -0.45 \\
\hline AHP LV, $\%$ & 0.50 & 0.04 & 0.52 & 0.07 \\
\hline PAR, mm & -0.02 & 0.01 & -0.05 & -0.20 \\
\hline AR, mm & $-0.41^{*}$ & -0.28 & -0.106 & -0.06 \\
\hline \hline
\end{tabular}

Note $1 .{ }^{*}$ Statistically significant correlation between the indicators $(\mathrm{p}<0.05)$. 
Table 3. Analysis of structural and functional parameters of the heart by echocardioscopy in patients with Conn's syndrome by gender

\begin{tabular}{c|c|c}
\hline \hline Indicator, unit of measure & Women $(\mathrm{n}=32)$ & Men $(\mathrm{n}=22)$ \\
\hline TIS, $\mathrm{mm}$ & $12.48 \pm 2.34$ & $13.07 \pm 3.42$ \\
\hline TPV LV, $\mathrm{mm}$ & $11.78 \pm 1.52$ & $12.81 \pm 3.31$ \\
\hline LVM, g & $238.91 \pm 65.19^{*}$ & $333.88 \pm 171.26^{*}$ \\
\hline SV $\%$ & $66.05 \pm 7.95$ & $66.80 \pm 8.41$ \\
\hline ESD LV, mm & $30.75(27.00 ; 34.00)^{*}$ & $32.42 \pm 7.75^{*}$ \\
\hline EDD LV,mm & $49.00(45.80 ; 54.00)^{*}$ & $53.66 \pm 7.54^{*}$ \\
\hline ECV LV, $\mathrm{mm}$ & $44.09 \pm 13.34$ & $50.95 \pm 24.17$ \\
\hline EDV LV, mm & $128.29 \pm 28.52$ & $150.49 \pm 43.17$ \\
\hline RL LV $\%$ & $13.50(10.24 ; 13.90)^{*}$ & $9.14(8.60 ; 11.22)^{*}$ \\
\hline CSBA LV, $\%$ & $17.10(15.97 ; 18.80)^{*}$ & $13.05(8.50 ; 15.87)^{*}$ \\
\hline AHP LV, $\%$ & $28.10(22.81 ; 34.60)^{*}$ & $15.95(10.07 ; 23.25)^{*}$ \\
\hline AHP LV, $\%$ & $19.10(16.95 ; 21.60)^{*}$ & $13.00(11.00 ; 15.13)^{*}$ \\
\hline \hline
\end{tabular}

Note 1. The data is given as $\mathrm{Me}(\mathrm{Q} 25 ; \mathrm{Q} 75)$ or $\mathrm{M} \pm \mathrm{m}$ depending on the nature of the data distribution. Note 2. * The probability of difference between 1 and 2 patient groups $(\mathrm{p}<0.05)$.

Significant differences were found between the first and third group for the SV $(p=0.035)$ and between the first and second groups for EDD ( $\mathrm{p}=$ 0.024). No substantial difference was found for the rest of the analyzed parameters in the three groups.

A strong negative correlation was demonstrated between SBP and the index of longitudinal strain of left ventricle at the base level $(r=-0.80, p<$ $0.05)$, a moderate negative correlation between the aortic root diameter and SBP level $(\mathrm{r}=-0.41, \mathrm{p}<0.05)$; a moderate negative correlation between the circumferential LV strain at the basal level and DBP $(\mathrm{r}=-0.56, \mathrm{p}<0.05)$; a moderate negative correlation between the circumferential LV strain at the base level and the aldosterone-renin ratio (ARR) $(r=-0.68, p<$ $0.05)$, as illustrated in Table 2. There was an inverse relationship between the adrenal adenoma size and the stroke volume (SV) $(r=-0.346, p<0.05)$.

The structural and functional parameters of the heart were analyzed separately for male and female patients (Table 3). In both groups, the IVST, TPW LV and LVM values exceeded the normal levels. The RL LV, CSBA LV, LDLC and AHP LV were abnormal in the males. Significant differences between the gender groups were demonstrated for MGMH $(\mathrm{p}<0.05)$, LDL $(\mathrm{p}<0.05)$, LDLC $(\mathrm{p}<0.05)$, LDLC $(\mathrm{p}<0.05)$, and SGR LS $(\mathrm{p}<0.05)$.

\section{DISCUSSION}

The speckle-tracking echocardiography is a recently developed technique that allows for detection of changes in the myocardial function at the early stages when the ejection fraction is still preserved. This method of cardiac sonography is angle independent and gives characteristics of myocardium motion in three planes (longitudinal, circular and radial) $(13,14)$. In the recent years, there has been an increase in the number of publications on abnormal myocardial contractility determined by speckle-tracking echocardiography, while the parameters measured by the conventional echocardiography, including the stroke volume, remained normal $(15,16)$. Changes in the longitudinal function of the myocardium precedes the development of LV hypertropy in HTN (17). In patients with hypertension, the reduction of longitudinal strain of $\mathrm{LV}$ leads to stroke volume decrease (12). In this study, we demonstrated deviations from the normal longitudinal, circular, and global strain of the LV with normal SV values in men with Conn's syndrome. These changes in myocardial deformation can be the predictors of systolic dysfunction.

In our opinion, the most sensitive parameter of LV strain is the global strain of the LV, which includes longitudinal strain and circular strain at the basal 
and apical levels, and characterizes the strain properties of the whole left ventricle.

The demonstrated correlation between the SBP and LSBA LV values $(r=-0.80$, it's $p<0.05)$ and between the DBP and LSBA LV values $(r=-0.56, p$ $<0.05)$ suggest that in Conn's syndrome, LV hypertrophy is preceded by changes not only in the longitudinal strain, but also the circular strain.

Unlike other etiologies of hypertension, in Conn's syndrome, an increase in the left ventricular mass results from an increase in the left ventricle size and thickening of the myocardium wall. It has also been postulated that increase in the left ventricle mass occurs without hypertrophy $(4,18,19)$. Our data suggest that the left ventricular hypertrophy was accompanied by increased LV mass.

Myocardial remodeling in the setting of elevated aldosterone secretion is mediated by the presence of mineralocorticoid receptors on the surface of cardiomyocytes (4). There was no correlation between the serum aldosterone level and echocardioscopic parameters in our patients, whereas a correlation between the echocardioscopic parametes and the value of aldosterone-renin ratio (ARR) was present suggesting the role of RAAS in the myocardial remodeling.

Muiesan ML et al. demonstrated increased LV mass in the absence of hypertrophy in patients with Conn's syndrome. Unlike patients with other forms of hypertension, the increase in the left ventricular mass exceeds the level required to compensate for the hemodynamic impacts on the cardiac muscle, which proves the role of aldosterone in myocardium remodeling (20). Our observations suggest that left ventricular myocardial hypertrophy in patients with Conn's syndrome develops simultaneously with the increase in the LV mass.

In patients with Conn's syndrome, the functional adenoma size may serve as a prognostic marker for stroke volume reduction, as evidenced by the negative correlation between these parameters $(\mathrm{r}=$ $-0.346, \mathrm{p}<0.05)$.

\section{CONCLUSIONS}

Echocardioscopy in patients with Conn's syndrome is a valuable method in the early detection of structural and functional changes of the heart and the degree of myocardium remodeling. In the majority of cases, Conn's syndrome is accompanied by changes in IVST, TLVPW, LVM, AR diameter, longitudinal, circular and global strain of the myocardium of LV due to both arterial hypertension and metabolic disarray. In patients with Conn's syndrome, abnormal echocardioscopic parameters are associated with blood pressure increase and ARR elevation. The changes in different components of myocardial deformation, namely longitudinal, circular and global strain of the left ventricle, precede the changes in the left ventricular stroke volume and can serve as a predictor of systolic dysfunction. Changes in thecircular strain at the base level and longitudinal strain precede LV hypertrophy and can be used as its early marker. 


\section{References}

1. Kaplan NM, Victor RG. Primary aldosteronism. In: Kaplan NM, Victor RG (eds.). Kaplan's clinical hypertension. Philadelphia: Wolters Kluwer; 2015: 320-40.

2. Vatutin NT, Shevelek AN, Degtyareva AE, Kasem SS. Rol' hiperaldosteronizma i perspektivy primenenia antagonistov al'dosterona pri rezistentnoi arterial'no i hipertenzii (obzorliteratyru) [The role of hyperaldosteronism and the prospects for using of aldosterone antagonists in resistant hypertension (literature review)]. Zhurnal Natsional'noi akademii meduchnukh nauk 2014; 20 (1): 43-51.

3. Monticone S, Burrello J, Tizzani D, et al. Prevalence and Clinical Manifestations of Primary Aldosteronism Encountered in Primary Care Practice. J Am CollCardiol2017;69(14):1811-20. doi: 10.1016/j.jacc.2017.01.052. https://doi.org/10.1016/j.jacc.2017.01.052

4. Catena C, Colussi G, Brosolo G, et al. Aldosterone and Left Ventricular Remodeling. Horm Metab Res 2015;47(13):981-6 https://doi.org/10.1055/s-0035-1565055

5. Luther JM. Aldosterone in vascular and metabolic dysfunction. Curr Op in Nephrol Hypertens 2016;25(1):16-21

https://doi.org/10.1097/MNH.0000000000000189

6. Prejbisz A, Warchoł-Celińska E, Lenders JW, et al. Cardiovascular Risk in Primary Hyperaldosteronism. Horm Metab Res 2015;47(13):973-80. doi: 10.1055/s-0035-1565124. https://doi.org/10.1055/s-0035-1565124

7. Sugimoto T, Dulgheru R, Bernard A, et al. Echocardiographic reference ranges for normal left ventricular 2D strain: results from the EACVI NORRE study. Eur Heart J CardiovascImaging

\section{https://doi.org/10.1093/ehjci/jex140}

8. Lang RM, Badano LP, Mor-Avi V, et al. Recommendations for cardiac chamber quantification by echocar- diography in adults: an update from the American Society of Echocardiography and the European Association of Cardiovascular Imaging. Eur Heart J Cardiovasc Imaging 2015;16(3):233-70. https://doi.org/10.1093/ehjci/jev014

9. Abduch MC, Alencar AM, Mathias WJr, et al. Cardiac mechanics evaluated by speckle tracking echocardiography. Arq Bras Cardiol 2014;102(4):403-12. https://doi.org/10.5935/abc.20140041

10. Smiseth OA, Torp H, Opdahl A, et al. Myocardial strain imaging: how useful is it in clinical decision making Eur Heart J 2016;37(15):1196-207. https://doi.org/10.1093/eurheartj/ehv529

11. Funder JW, Carey RM, Mantero F, et al. The Management of Primary Aldosteronism: Case Detection, Diagnosis, and Treatment: An Endocrine Society Clinical Practice Guideline. J Clin Endocrinol Metab 2016;101(5):1889-916. https://doi.org/10.1210/jc.2015-4061

12. Funder JW, Carey RM, Fardella C, et al. Case Detection, Diagnosis, and Treatment of Patients with Primary Aldosteronism: An Endocrine Society Clinical Practice Guideline. The J Clin Endocrinol Metab2008; 93 (9): 3266-81. https://doi.org/10.1210/jc.2008-0104

13. Abduch MC, Alencar AM, Mathias WJr, Vieira ML. Cardiac mechanics evaluated by speckle tracking echocardiography. Arq Bras Cardiol 2014;102(4):403-12.

https://doi.org/10.5935/abc.20140041 
14. Smiseth OA, Torp H, Opdahl A, et al. Myocardial strain imaging: how useful is it in clinical decision making Eur Heart J 2016;37(15):1196-207. https://doi.org/10.1093/eurhearti/ehv529

15. Lo CI, Lai YH, Wu JJ, et al. Cardiac systolic mechanics in heart failure with preserved ejection fraction: new insights and controversies. Acta Cardiol Sin 2013;29(6):515-23.

16. Nikiforov VS, NikishchinkovaYuV. Sovremennye vozmozhnosti speckle tracking ekhokardiografii v klinicheskoi praktike [Modern capabilities of speckle tracking echocardiography in clinical practice]. Ratsional'naya farmakoterapiya $\mathrm{V}$ kardiologii 2017; 13 (2), 248-55.

https://doi.org/10.20996/1819-6446-2017-13-2-248$\underline{255}$

17. Smiseth OA, Torp H, Opdahl A, et al. Myocardial strain imaging: how useful is it in clinical decision making Eur Heart J 2016;37(15):1196-207.

https://doi.org/10.1093/eurheartj/ehv529

18. Milan A, Magnino C, Fabbri A, et al. Left heart morphology and function in primary aldosteronism. High Blood Press Cardiovasc Prev 2012; 19: 11-7

https://doi.org/10.2165/11593690-000000000-00000

19. Indra $T$, Holaj $R$, Zelinka $T$, et al. Left ventricle remodeling in men with moderate to severe volume-dependent hypertension. J Renin Angiotensin Aldosterone Syst 2012; 13: 426-34 https://doi.org/10.1177/1470320312446240

20. Muiesan ML, Salvetti M, Paini A, et al. Inappropriate left ventricular mass in patients with primary aldosteronism. Hypertension 2008; 52: 529-34.

https://doi.org/10.1161/HYPERTENSIONAHA.10 8.114140 


\title{
Primarni aldosteronizam: analiza dobijena speckle tracking ehokardiografijom
}

\author{
Andryi Nykonenko ${ }^{1}$, Iryna Zubryk ${ }^{1}$, Oleksandr Podluzhnyi ${ }^{1}$, Olrksandr Molodan², Sergii Bukhtii ${ }^{3}$, \\ Oleksandr Nykonenko ${ }^{2}$ \\ ${ }^{1}$ Državni medicinski Univerzitet Zaporizhzhya, Zaporizhzhya, Ukrajina \\ ${ }^{2}$ Državni departman "Medicinska akademija za postdiplomsko obrazovanje ukrajinskog \\ Ministarstva zdravlja Zaporizhzhya", Zaporizhzhya, Ukrajina \\ ${ }^{3}$ Vinmec Internacionalna bolnica JCI, Departman za anesteziologiju $i$ \\ lečenje bola, Hanoj, Vijetnam
}

\section{SAŽETAK}

Remodelovanje miokarda kod bolesnika sa primarnim aldosteronizmom obavlja se preko mineralno kortikoidnih receptora smeštenih na miocitima i fibroblastima. Cilj ove studije bila je analiza efekata arterijske hipertenzije i metaboličkih poremećaja na kardiovaskularni sistem bolesnika sa primarnim aldosteronizmom.

Ova studija uključila je 54 bolesnika sa primarnim aldosteronizmom, od kojih su 32 (61,1\%) osobe bile ženskog i $22(38,9 \%)$ osobe muškog pola. Prosečna starost bolesnika iznosila je 51,95 godina $\pm 13,77$ godina.

Zabeležena je statistički značajna negativna korelacija između sistolnog krvnog pritiska i longitudinalnog strain-a leve komore u nivou baze srca; umerena negativna korelacija između longitudinalnog strain-a leve komore u nivou baze srca i prečnika korena aorte; negativna korelacija između cirkuferencijalnog strain-a leve komore u nivou baze srca i sistolnog krvnog pritiska, kao i negativna korelacija između cirkuferencijalnog strain-a leve komore u nivou baze srca i odnosa između aldosterona $i$ renina. Dobijene korelacije između sistolnog krvnog pritiska i longitudinalnog strain-a leve komore u nivou baze srca, dijastolnog krvnog pritiska i cirkuferencijalnog strain-a leve komore u nivou baze srca ukazuju na to da hipertrofiji leve komore, kod primarnog aldestorenozma prethodi ne samo smanjenje longitudinalnog strain-a, što je prethodno i pokazano, već i smanjenje cirkularnog strain-a.

Ključne reči: primarni aldosteronizam, hipertenzija, ehokardioskopija, dijagnoza 